\title{
Non-Governmental Aid Organisations in Afghanistan Between Impartiality and Counterinsurgency
}

\author{
Robert Lindner*
}

\begin{abstract}
In a complex emergency as in Afghanistan, most non-governmental aid organisations interact with military actors on the basis of a clearly defined set of principles and rules. Independence, impartiality and acceptance are the prerequisite for them to gain safe access to people in need. However, as ISAF troops are using aid as a tactical means within a military-led counterinsurgency strategy, NGOs and their beneficiaries increasingly get targeted by insurgents. Militarised aid is also not effective to promote security. Without addressing the root causes of conflict, without bringing justice to the victims of violence and without maintaining human rights, any efforts towards peace and reintegration will be pointless.
\end{abstract}

Keywords: Civil-Military Cooperation, counterinsurgency, humanitarian principles, reintegration, peace building Zivil-militärische Zusammenarbeit, Aufstandsbekämpfung, humanitäre Prinzipien, Reintegration, Friedensaufbau

\section{Introduction}

W hen it comes to interaction with military actors in complex emergencies like in Afghanistan, independent non-governmental aid agencies like Oxfam and others - which are joined together in VENRO, the German umbrella organisation of development aid organisations - are operating under clear principles: never to be a part of a military strategy such as the NATO counterinsurgency concept (COIN). Their engagement - be it short-term humanitarian or long-term development - is solely guided by the needs of their target groups on the ground: those civilians most vulnerable to armed conflict and human rights abuses and suffering most from chronic poverty. If independent aid organisations supported military goals, their impartiality would be compromised and they would risk forfeiting their acceptance by the people. There is a broad consensus among independent aid organisations that acceptance is a prerequisite for a secure working environment. If NGOs get too deeply engaged with the military, even with ISAF or other legitimate forces, lines between the civil and military sphere can get dangerously blurred. That makes it easy for insurgents to discredit aid workers as enemies and identify them as legitimate targets for attack. The security of both NGO staff and beneficiaries is seriously put at risk. Ultimately, agencies can lose access to people in need.

However, this does not mean that independent development and humanitarian aid organisations refuse any cooperation or communication with legitimate military forces. In Afghanistan and elsewhere, aid agencies and military actors frequently operate in close proximity. Hence, interaction is almost inevitable, but it has to occur in a way that respects the respective needs and restrictions on both sides.

* Robert Lindner works with Oxfam Germany in Berlin as policy advisor on humanitarian affairs. The views expressed herein are his personal views.

\section{NGO and other guidelines on civil-military relations}

There are plenty of principles and guidelines governing the interaction between aid organisations and military actors, most notably the Red Cross / Red Crescent Code of Conduct, the "Oslo Guidelines"1, the EU Consensus on Humanitarian Aid and the Sphere Handbook. All these documents clearly state the need to keep the humanitarian and military mandates separately and therefore disqualify warring parties as humanitarian actors. Most troop-contributing countries engaged in Afghanistan have committed themselves to one of those sets of rules.

In a position paper, VENRO outlined its policy regarding opportunities and limits of the cooperation between the military and aid organisations on humanitarian relief. It calls upon armed forces to respect the independent status of aid organisations. Cooperation within military-guided civil support operations is rejected, due to concerns over neutrality and independence of humanitarian agencies. ${ }^{2}$

The German Welthungerhilfe developed practical guidelines for the management of interaction with armed forces in complex emergencies like in Afghanistan. This document concisely describes opportunities and limits for NGO cooperation with different actors in an armed conflict.

Basically, the guidelines consider if respective armed forces are a "party involved in conflict" (national armies, non-government armed players, UN missions according to Chapter VII Article 42 , NATO, occupying power)". In this case, "interaction between the armed forces and NGO is limited to the sharing of work-related information, i.e. exchanges about which measures are to be implemented in which regions with which staff". Importantly, the rules apply equally to all parties involved

1 Guidelines on the Use of Foreign Military and Civil Defence Assets In Disaster Relief - "Oslo Guidelines" (2006/2007), http://www.unhcr.org/refworld/type ,OPGUIDELINE,,,47da87822,0.html.

2 VENRO-Positionspapier (2003): “Streitkräfte als humanitäre Helfer”, p. 19 http://www.venro.org/fileadmin/Publikationen/Einzelveroeffentlichungen/ Humanitaere_Hilfe/Positionspapier\%20Streitkraefte\%20und\%20humanitae re\%20Hilfe.PDF. 
in the conflict, thus reaching beyond relations with regular forces.

Welthungerhilfe prohibits staff from passing on security-related information to conflict parties. This principle is communicated to all conflict parties. Even if the transfer of such information could increase the efficiency of relief efforts, "it is extremely difficult to assess the impact this information may have", because this information could be used to facilitate military operations, thus compromising the aid agency's impartiality.

Finally, for a possible partnership or joint implementation of humanitarian aid by military and NGOs the guidelines are clear: "Welthungerhilfe generally avoids the joint implementation of projects under a common management with armed actors ... NGOs pursue different goals to military forces: they should not therefore be described as partners by the military. NGOs are not implementation partners that carry out the humanitarian activities of military forces." 3

As for Afghanistan, the UN, NGOs, NATO-led troops and the Afghan government forces agreed to a set of "Civil-Military Guidelines" in August 2008. This document reiterates the international humanitarian principles in order to communicate them to relevant military actors. An example is the right of aid workers not to share information with the military, if it could be used for military purposes and might endanger lives. The guidelines also state that only "in exceptional circumstances and as a last resort, military assets ... may be deployed for the purpose of providing humanitarian assistance"4.

One of the Guidelines' major achievements so far has been a directive for NATO-led Provincial Reconstruction Teams (PRTs) to abstain from providing humanitarian assistance, unless specifically called upon by the civil authorities. It reiterates a PRT Executive Steering Committee Policy Note from 2007, stating that humanitarian assistance "must not be used for the purpose of political gain, relationship building, or 'winning hearts and minds' ... and must uphold the humanitarian principles of humanity, impartiality and neutrality" ${ }^{\text {. Another }}$ achievement of the Guidelines is NATO's recognition that differentiation between combatants and non-combatants is crucial, as well as their directive for NATO troops to no longer use white-coloured vehicles as of May 2009.

Basically, the Guidelines provide a clearly defined and accepted framework for the interaction between the humanitarian community and the military in Afghanistan. However, according to a report by Oxfam International, published in the run-up to the London conference in late January 2010, the Guidelines have largely remained rhetorical. Oxfam criticises that "little progress has been made since the Guidelines were endorsed ... It is unclear whether the Guidelines are actually being followed - or even the extent to which they have been

3 Deutsche Welthungerhilfe, "Cooperation with Armed Forces", Policy Paper No. 1/2008, http://www.welthungerhilfe.de/fileadmin/media/pdf/Englische_ Seite/Policy paper CIMIC neu2.pdf.

4 Afghanistan Civil Military Working Group: "Guidelines for the Interaction and Coordination of Humanitarian Actors and Military Actors in Afghanistan “(2008), http://ochaonline.un.org/OchaLinkClick.aspx?link=ocha\&docId=1 112406.

5 PRT Executive Steering Committee, "PRT Policy Note 3: PRT Coordination and Intervention in Humanitarian Assistance", 22 February 2007, http:// www.unamagroups.org/kabulprtworking group. disseminated ... No systematic mechanisms have been put in place to monitor compliance with the Guidelines". Other members of the humanitarian community even speak of the Guidelines "half-failure". ${ }^{6}$

\section{Use of aid as a force multiplier?}

As stated above, civil-military cooperation is not a bad thing per se. But to an increasing extend states, which are engaged as donors and troop contributors in Afghanistan, go far beyond what most NGOs can tolerate. This is particularly true for NATO's overarching strategy to integrate military and civil efforts in Afghanistan in order to make its military mission more effective. NATO Deputy Secretary General Ambassador Claudio Bisogniero explained in January 2008: “This Comprehensive Approach ... means first of all the effective coordination of military and civil elements ... In planning and conducting its operations, NATO has always sought to embed them in a wider framework, linking the provisions of security to the pursuit of reconstruction and development."7 The German version of the Comprehensive Approach, the so-called "Networked Security" , uses the catch phrase: "No development without security, no security without development."

From a purely military perspective, such an approach is undoubtedly attractive. Given the worsening security situation in Afghanistan, along with the under-resourced international forces and an underdeveloped Afghan army, it is somewhat understandable that ISAF increasingly engages in relieve and reconstruction activities in order to win the "hearts and minds" of the civilian population, and thus to deprive insurgents of their support. Following this logic, not only the constructions of bridges and roads but also humanitarian and development aid are increasingly used as force multipliers. The "civilian surge", proclaimed by the USA and some of their allies, can also be more or less subsumed under that approach. In order to mobilise as many civil resources as possible, many NATO states increasingly put pressure on non-governmental aid organisations to cooperate with their military forces in Afghanistan.

One US army manual even defines aid bluntly as "a nonlethal weapon" that can be used to "win the hearts and minds of the indigenous population to facilitate defeating the insurgents"10. Other NATO members put that concept in more moderate

6 Laurent Saillard, director of ACBAR, "Afghanistan - How should aid workers, military personnel interact?", IRIN News, 28 October 2009, http://www.irinnews.org/Report.aspx?ReportId=86776.

7 NATO Deputy Secretary General Ambassador Claudio Bisogniero, "Assisting Afghanistan: The importance of a comprehensive approach", Keynote address at the GLOBSEC Conference, 17 January 2008, http://www.nato.int/docu/ speech/2008/s080117a.html.

8 According to the German government, "Networked Security" was even the forerunner of the "Comprehensive Approach".

9 Bundesministerium der Verteidigung, "Unsere Bundeswehr in Afghanistan - Für Sicherheit und Frieden", December 2009, p. 14 http://www.bundeswehr. de/fileserving/PortalFiles/C1256EF40036B05B/W276ZEPQ607INFODE/Brosc huere\%20Afghanistan\%20Sprachversion.pdf.

10 US Army Combined Arms Center, "Commanders' Guide to Money as a Weapons System: Tactics, techniques and Procedures", April 2009, quoted after: "Quick Impact, Quick Collapse - The Dangers of Militarized Aid in Afghanistan", see note 18 . 
terms, but in general there is a clear tendency among donor/ troop-contributing countries to exploit aid for military ends.

As for Germany, Development Minister Dirk Niebel complained in an interview in December 2009 about "some non-governmental organizations", which "want to maintain a certain distance from the Bundeswehr", and made clear that if NGOs are not ready to cooperate with the German army, "they need to look for other donors" ${ }^{11}$.

\section{Militarised aid and collateral damage}

Reacting to the strong public criticism by VENRO and several German aid organisations against his plans, Mr. Niebel explained that he did not aim to create "embedded aid workers" and did not want to pursue a militarisation of development policy. Instead, his intention was to interlink the work of the Bundeswehr and of German aid organisations on the ground more closely in order to increase the coherence of the whole German effort. Finally, the Minister said that he would disagree with NGO critics stating that closer civil-military cooperation would jeopardise the civil reconstruction in Afghanistan; saying that rather "the opposite is the case."12

However, many NGOs, academics and UN officials share the opinion that military engagement in civil reconstruction in Afghanistan endangers people and projects. ${ }^{13}$ Oxfam and other aid organisations are witnessing high levels of violence against aid workers and are seeing clear evidence that the military's involvement in development activities is putting Afghan people and staff of aid agencies on the frontlines of the conflict. A report released by CARE, the Afghan Ministry of Education and the World Bank found that schools supported or constructed by PRTs were perceived by Afghans to be at higher risk of being attacked. ${ }^{14}$ With anti-government elements increasingly targeting education infrastructure, schools built by the military in insecure areas represent a greater risk for teachers and students. As a result, parents were less likely to send their children, especially girls, to school. One local official in Daikundi said to researchers: "We are very poor and need development projects, but we know that wherever the international forces go, the Taliban follow them."15

UN officials have repeatedly seconded NGO's criticism. Mr Wael Haj-Ibrahim, head of the United Nations' Office for the Coordination of Humanitarian Affairs in Kabul, argued that delivering aid as part of a military or political strategy only

11 Johannes Gernert: “Niebel will Helfern den Hahn abdrehen”, FR-online.de, 29 December 2009, http://www.fr-online.de/in_und_ausland/politik/aktuell/ ?em_cnt=2171455\&em_comment_page $=14$.

12 Interview on Mr. Niebel's website, 21 March 2010, http://www.dirk-niebel.de/ Ich-werde-mehr-tun-als-meine-Vorgaengerin/24780c1i1p1315/index.html.

13 See for instance: "Hilfsorganisationen kritisieren Minister Niebel: Militarisierung der Entwicklungshilfe befürchtet", Netzeitung.de, 29 December 2009, http://www.netzeitung.de/politik/deutschland/1538499.html.

14 Marit Glad, "Knowledge on Fire: Attacks on Education in Afghanistan, Risks and Measures for Successful Mitigation", CARE/Ministry of Education/ World Bank, November 2009, http://www.care.ca/ckfinder/userfiles/files/ Knowledge_on_fire-attacks_\%20schools.pdf.

15 Ashley Jackson, "Quick Impact, Quick Collapse - The Dangers of Militarized Aid in Afghanistan", published by Action Aid, Afghanaid, CARE, Christian Aid, Concern Worldwide, Norwegian Refugee Council, Oxfam and Trocaire, http://www.oxfam.de/publikationen/quick-impact-quick-collapse. provokes insurgents to engage in the "counter-strategy" to destroy such aid. ${ }^{16}$

This is particularly true for the so-called "post-battlefield cleanup" concept, developed within the US counterinsurgency strategy. After troops rid an area of insurgents, civilian actors are supposed to contribute to distribution of aid. William Frej, head of the USAID mission in Afghanistan, defends this concept: "Without COIN and without the military's support, many of the humanitarian agencies ... would not be able to enter the areas once controlled by insurgents." 17 However, NGOs like Oxfam, which have been working for decades in Afghanistan and other crisis countries, come to different conclusions. There has hardly been a case, where a partnership with the military has been helping them. On the contrary, task-sharing as understood by COIN proponents would not only constitute a breach of humanitarian principles, it would also endanger the lives of NGO staff, due to the risk of being associated with the military effort and thus getting targeted by armed opposition groups.

In contrast to widespread belief, Taliban and other armed opposition groups are not systematically targeting NGOs or demonising them as agents of evil powers. According to the Afghanistan NGO Safety Office (ANSO), insurgents seem to be making some effort to distinguish between neutral and non-neutral actors: "Neutrality and local acceptance, not the military or counter-insurgency, have become the dominant factors of security for NGOs in the vast areas of the country now dominated or controlled by the Taliban and other armed opposition groups." 18

Furthermore, there are strong indications that aid as part of COIN is not only dangerous but also ineffective. According to Mr. Haj-Ibrahim, UN OCHA (UN Office for the Coordination of Humanitarian Affairs) lead in Kabul, allowing the military to provide assistance "is not the best use of resources". He said that instead, the military should confine itself to clearing an area of security threats and providing security for humanitarian organisations to deliver services. ${ }^{19}$ Researchers at the Feinstein International Center at Tufts University in Boston came to similar findings: that there was very little evidence of aid projects winning hearts and minds or promoting stability. Wrong aid can even destabilise the situation: "Spending too much too quickly with too little oversight in insecure environments is a recipe for fuelling corruption, delegitimizing the Afghan government, and undermining the credibility of international actors." 20

Part of the problem is that militarised aid focuses on quick impact rather than on long-term solutions based on need. Too

16 Press conference of 17 February 2010 in Kabul on the launch of the Humanitarian Action Plan 2010, http://unama.unmissions.org/Default. aspx?tabid=1761\&ctl=Details\&mid=1892 \&ItemID=7810.

17 IRIN news, 2 December 2009, "Afghanistan: USAID rejects NGO concerns over aid militarization", http://www.irinnews.org/Report.aspx?ReportId=87288.

18 IRIN news, 20 January 2010, "Afghanistan: Warning over heightened risk to NGO staff in 2010", http://www.irinnews.org/Report.aspx?ReportId=87802.

19 Press conference of 17 February 2010 in Kabul on the launch of the Humanitarian Action Plan 2010, http://unama.unmissions.org/Default. aspx?tabid $=1761 \& c t l=$ Details\&mid $=1892 \&$ ItemID $=7810$.

20 Andrew Wilder und Stuart Gordon, "Money can't buy America Love“, Foreign Policy, 1 December 2009, http://www.foreignpolicy.com/articles/2009/12/01/ money_cant_buy_america_love. 
often, such projects lack proper design and implementation. According to a report to the US Congress, one school constructed by a US-lead PRT in Kapisa province had problems with its structural integrity and serious design flaws, with latrines emptying just above a stream that the community used as a water source. ${ }^{21}$

Even some responsible authorities are aware of potential harms of aid which is aimed to support military goals. A recent US government audit of projects funded by the Commanders' Emergency Response Program (CERP) found that there was insufficient monitoring of the impact of projects and expressed concern about the lack of financial oversight. ${ }^{22} \mathrm{An}$ evaluation report of the German Federal Ministry for Economic Cooperation and Development from March 2010 questions a common assumption within the hearts and minds concept: "Using development aid to influence acceptance of foreign troops is not effective." 23

\section{Beyond the aid-stabilisation postulate}

A survey among Afghans in fourteen provinces conducted in 2009 by several non-governmental organisations operating in Afghanistan revealed that poverty is the greatest driver of violence in Afghanistan, followed by corruption and ineffectiveness of the Afghan government. ${ }^{24}$ None of these problems alone can be made responsible for the protracted conflict, but they are all constantly fuelling violence. Hence, the provision of aid might in some cases contribute to reducing levels of violence, but can hardly serve as a panacea to bring peace and stability to conflict areas. The authors of the aforementioned survey commissioned by the German Development Ministry are even more sceptical about the positive effects of aid projects on security, for example: "More aid does not reduce threats. To the contrary ... the reverse seems to be true. Those who report having received aid also feel more threatened." 25

According to most independent humanitarian and development agencies, aid has to follow the needs of their target groups, not any security policy goals. It goes without saying that it is easier to operate in a secure environment, but there are many NGOs which are able to conduct aid programmes also in regions without a monopoly of force by accountable wielders of power. For example, Oxfam has continued to run programmes not only before and after the long periods of fighting since 1978,

21 “Quick Impact, Quick Collapse“, p. 2, op. cit.

22 ibid.

23 Federal Ministry for Economic Cooperation and Development (BMZ), "Assessing the Impact of Development Cooperation in North East Afghanistan 2005 - 2009", Final Report, March 2010. The study has been carried out by Christoph Zürcher (team leader), Jan Böhnke and Jan Koehler of the Research Centre 700, Free University of Berlin, http://www.bmz.de/en/service/ infothek/evaluation/BMZEvaluierungsberichte/BMZ_Eval049e_web.pdf.

24 "The Cost of War", published by Afghan Civil Society Forum (ACSF), Afghan Peace and Democracy Act (APDA), Association for the Defence of Women's Rights (ADWR), Cooperation Centre for Afghanistan (CCA), Education Training Center for Poor Women and Girls of Afghanistan (ECW), Oxfam GB, Organization for Human Welfare (OHW), Sanayee Development Organization (SDO) and The Liaison Office (TLO), November 2009, http://www.oxfam.de/ publikationen/cost-war-afghan-experiences-conflict-1978-2009.

25 Federal Ministry for Economic Cooperation and Development (BMZ), "Assessing the Impact of Development Cooperation in North East Afghanistan 2005 - 2009", p. 36, op. cit. but to a certain extent also during the Soviet occupation, the subsequent civil war, and even under the Taliban era.

Security and stability are no ends in themselves. They are nothing without human rights and dignity. During the rule of the Taliban, large parts of Afghanistan were more or less stable, but many people were at risk of cruel, inhuman or degrading treatment, or punishment, or suffered extreme poverty.

If not poverty or lack of aid, what other factors are responsible for the decrease of security in many parts of Afghanistan? International academics and experts from donor and troop contributing countries, who met at a Wilton Park Conference to reflect on the effectiveness of the 'hearts and minds' approach in Afghanistan ${ }^{26}$, considered in their final report the frustration of many Afghans with their own government, which they perceived as "massively corrupt, predatory and unjust" and as a major source of insecurity. This coincides with findings on the feasibility of peace talks with the Taliban that, besides retaliation against a perceived foreign military aggression and threat to Afghan and Islamic values, an important motivation for many fighters consists of their "resistance to officials regarded as dishonest, corrupt, and unjust, who benefit from impunity". Economic and social factors themselves do not constitute a cause for fighting, although "poverty and unemployment help a lot with recruitment" ${ }^{27}$. It almost goes without saying that any counterinsurgency strategy, which is relying on the use of aid to win over the population to support the international intervention and Afghan authorities, is pointless, when people have more trust in the Taliban's abilities to address their most pressing problems. Neither military nor civilian efforts - alone or as a hybrid - will bring peace and stability to Afghanistan, as long as the international community and the Afghan government are not getting the politics right. Without addressing the root causes of poverty, combating corruption, and providing justice, any push for more security and stability will fail.

\section{Resolving conflict? The quest for peace}

At the Peace Jirga, which was convened from 2-4 June 2010 in Kabul, President Hamid Karsai launched the Afghanistan Peace and Reintegration Programme (APRP). Heavily funded by Western donor countries, the APRP has been designed to persuade fighters of the Taliban and other insurgent groups to give up their arms and return to their communities. However, there are serious doubts if the programme will succeed to pacify Afghan society. At most it will peel "some fighters

26 Report on Wilton Park Conference 1022: “'Winning Hearts and Minds' in Afghanistan: Assessing the Effectiveness of Development aid in COIN Operations", p. 2. - The conference was organised in partnership with the Feinstein International Center, Tufts University with support from the Australian Agency for International Development (AusAid), the Asia Pacific Civil-Military Centre of Excellence, the Royal Norwegian Ministry of Foreign Affairs, the Swedish International Development Cooperation Agency (SIDA), and the British Foreign and Commonwealth Office (FCO). Report http://usacac.army.mil/cac2/coin/repository/Assesing_Effectiveness_of_ Development_Aid_in_COIN_\%281_Apr_10\%29.pdf.

27 Matt Waldman, "Dangerous Liaisons with the Afghan Taliban. The Feasibility and Risks of Negotiations", United States Institute of Peace, Special Report 256, October 2010, p. 4, http://www.usip.org/publications/dangerousliaisons-the-afghan-taliban. 
away from the insurgency and thus gradually reduce the level of violence, but as long as there is no inclusive peace and reconciliation process in place, reintegration efforts simply do not make sense. Furthermore, victims of past atrocities have reservations that the APRP might result in impunity for their tormentors. The overwhelming majority of Afghans want peace, but not at any cost. Perpetrators must be brought to justice, and victims have to be provided with full redress. In particular, any serious initiative for peace and reconciliation must also acknowledge the immense suffering of women during the Afghan war. In the run-up to the international Kabul conference in July 2010, Afghan women's rights activists demanded that "Women's rights and achievements should not be compromised in any peace negotiations or accords" and called for "rigorous monitoring and redress" 28 . Regarding the APRP, a fair proportion of the funding provided through the Peace and Reintegration Trust Fund should ensure that financial incentives for communities to support reintegration are used to support women's empowerment and development.

Besides bringing justice to the victims of past and ongoing human rights violations, it is imperative to resolve the root causes of conflict. Violence in Afghanistan does not always follow a genuine political agenda. Quite often it stems from local disputes over land and water or inter-community differences.

28 Statement by the Afghan Women's Movement from First Women's Council to the Kabul Conference, 17-18 July 2010, http://www.peacewomen.org/portal_ initiative_initiative.php?id=378.
A range of factors such as natural disasters, refugee flows, corruption, or abuse of power can aggravate those quarrels and turn them into systematic violence. Decades of war have severely damaged the social fabric of the country, so traditional mechanisms for the resolution of disputes, such as community or tribal councils of elders, have become dysfunctional.

However, peaceful means of conflict resolution and prevention have been widely neglected by donor countries and the Afghan government so far. The Afghan National Development Strategy (ANDS), launched at the international donor conference in Paris in June 2008, just cursorily mentions peace building, but does not identify it as its own field of action. Given the fact that existing initiatives in Afghanistan have often proved to be effective at mediating local conflicts and helping to restore social cohesion, donors should provide much greater support for successful programmes such as the elected Community Development Councils (CDCs) under the National Solidarity Programme (NSP). What's more, in order to upgrade peaceful conflict resolution within Afghan development politics, a national strategy for peace building should be established. The upcoming renewal of the Afghanistan Compact would be a good opportunity for donors and the Afghan government to make up for what they have missed for far too long. ${ }^{29}$

29 Matt Waldman, "Community Peacebuilding in Afghanistan - The Case for a National Strategy", Oxfam International Research Report, February 2008, http://www.oxfam.de/publikationen/community-peacebuildingafghanistan-\%E2\%80\%93-case-national-strategy.

\title{
Towards a comprehensive approach? The EU's contribu- tion to Security Sector Reform (SSR) in Afghanistan
}

\author{
Eva Gross*
}

\begin{abstract}
This article analyzes the EU's contribution to Security Sector Reform (SSR) in Afghanistan. It places EU efforts, particularly those aimed at reforming the Afghan National Police (ANP), in the context of the broader international engagement in Afghanistan and the pursuit of a comprehensive approach that aligns civilian and military efforts. It argues that establishing a working division of labor and coordination between the NATO training mission NTM-A and EUPOL Afghanistan presents a significant challenge. The institutional actors engaged in reforming Afghanistan's security sector have not yet succeeded in building a comprehensive approach in Afghanistan's reconstruction.
\end{abstract}

Keywords: SSR, EUPOL Afghanistan, police reform, comprehensive approach

SSR, EUPOL Afghanistan, Polizeireform, umfassender Ansatz

\section{Introduction}

S ecurity Sector Reform (SSR) - that is, strengthening and reforming those institutions that are key to establishing and maintaining the rule of law under local ownership, accountability and democratic control - constitutes both an

* Prof. Dr. Eva Gross is Senior Research Fellow at the Institute for European Studies, Vrije Universiteit Brussel. This article is double-blind peer-reviewed. integral and an essential element of post-conflict reconstruction. In the context of the international engagement in Afghanistan, improving security, governance and the rule of law is a crucial element for the transition towards Afghan ownership of its security institutions. It is also a primary condition for the eventual reduction of military commitments on the part of the US and its allies. Finally, SSR efforts represent an important component of the implementation of a comprehensive 